\section{„RARYTNE” CZASY. O PRZEŁOMIE \\ ROMANTYCZNYM W KSIĘGARZU ULICZNYM WŁADYSŁAWA SYROKOMLI}

Mając mówić o literackiej wizji przełomu romantycznego z perspektywy biografii Syrokomli i jego czasów, a więc raczej końca romantyzmu, chciałabym zacząć od wydarzeń 1822 roku. Powstał wówczas wiersz Mickiewicza Do Joachima Lelewela, który nie dotyczy jedynie problemów „historyki” i jej dylematów ani też tylko Lelewelowskiego wykładu dziejów (w recepcji poety). Mickiewicz wychodzi od innego zespołu zagadnień - wiążą się one $\mathrm{z}$ atmosferą Wilna roku 1822 oraz lat bezpośrednio ten czas poprzedzających - do czego poetę skłania okolicznościowy charakter utworu, poświęconego ponownemu objęciu katedry historii przez Joachima Lelewela (1822), a także pierwszej jego profesurze. Wiersz skierowany do Lelewela stanowi ważny komentarz do przełomu romantycznego, formułowany w chwili jego dokonywania się - jeśli wierzymy w rewolucyjny charakter tej zmiany - i to przez głównego jego „sprawcę”. Przynależy zatem do zbioru tekstów Mickiewicza z 1822 roku, składających się na macierzysty kontekst przełomu, takich jak: Romantyczność, Pierwiosnek, O poezji romantycznej.

Do Joachima Lelewela nie przynosi rozbudowanych, autonomicznych obrazów Wilna 1822 roku, raczej są to migawki, które pojawiły się w wierszu w funkcji charakterystyki pośredniej adresata utworu. Pośród owych migawek widzimy i taką, która dotyczy kultury książki w uniwersyteckim Wilnie, a nawet rynku książki. Lelewel ma być mianowicie autorem zupełnie innego rodzaju niż ten, 
[...] co wielkość całą gruntuje w dowcipie,

Rad tylko, że swe imię szeroko rozsypie

I że barki księgarzom swymi pismy zgarbi ${ }^{1}$.

[w. 5-7]

Pochwała wyraża się w przekonaniu - to zresztą niejedyna lekcja tego fragmentu - że bohater wiersza nie wydaje wiele i lada czego. Nie drukuje dla „sławy”, tylko „sercem spółrodaka żyje między braćmi” (w. 10), wsłuchuje się zatem w potrzeby odbiorców. W rezultacie i tak „sławą" przyćmiewa innych, o czym świadczy wers: „imię twoje wybiegło za Chrobrego szranki" (w. 15). Sam Lelewel w Panowaniu króla polskiego Stanisława Augusta... za główną zaletę zreformowanego w oświeceniu polskiego szkolnictwa uważał kształcenie obywatelskie, nadające wysoką rangę właśnie takim dziedzinom, jak historia i literatura ${ }^{2}$. Możemy zatem wnosić, że „życie sercem” pośród braci zaowocowało rozumieniem takich właśnie, obywatelskich, oczekiwań czytelników. Jednak nie o czytelnikach w przytoczonym fragmencie mowa, ale o pośrednikach, owych „księgarzach”, na „barkach” których „sława” autorów rozchodzi się po świecie. Przyzwyczajeni jesteśmy myśleć o księgarni Zawadzkiego jako miejscu i instytucji obok sieci podległych uniwersytetowi szkół - niesłychanie ważnym dla popularyzacji pism, nowych idei, pomysłów organizowania się społecznego, wychodzących z kręgu wileńskiej uczelni. Wiele w tym racji, księgarnia ta zarówno podczas studiów Lelewela, jak Mickiewicza była kuźnią wielu inicjatyw ${ }^{3}$, punktem kontaktowym pomiędzy autorami i czytelnikami książek. Ale nie jedynym, bo - jak dowiadu-

1 Adam Mickiewicz, Do Joachima Lelewela. Z okoliczności rozpoczęcia kursu historii powszechnej w Uniwersytecie Wileńskim, dnia 9 stycznia 1822 r., w: Dzieła, t. I: Wiersze, oprac. Czesław Zgorzelski, Warszawa 1993, s. 141-148.

2 Joachim Lelewel, Panowanie króla polskiego Stanisława Augusta Poniatowskiego obejmujące trzydziestolecie usilności narodu podźwignienia się, ocalenia bytu i niepodległości, w: tegoż, Dzieła, t. VIII, oprac. Józef Dutkiewicz, Marian H. Serejski, Helena Więckowska, Warszawa 1961, s. 351, 353.

3 Zawadzki był również wydawcą czasopism, m.in. „Tygodnika Wileńskiego”, który wymyślił i zainicjował Lelewel, a debiutował w nim Mickiewicz. Zob. Wiktor 
jemy się z wiersza Mickiewicza - istnieli też księgarze innego typu. Ich rolę i znaczenie ukazuje wilnianin o pokolenie młodszy od Lelewela i Mickiewicza - Władysław Syrokomla (właśc. Ludwik Kondratowicz) w wierszowanej gawędzie Księgarz uliczny, w której powraca do czasów „pana Joachima” i „pana Mickiewicza”.

Syrokomla „Nestorem księgarzy” nazywa żydowskiego księgarza ulicznego, obnośnego i obwoźnego, dzięki któremu dokonała się doniosła zmiana oświatowa, polegająca na przejściu od epoki „wileńskiego kalendarza” i karczmy ( $\mathrm{z}$ „arendarzem” zamiast gazety) do czasów księgarni: „Dziś cała Litwa czyta, dziś wszystko jej znane”4. Gawęda jest interesującą kartką z dziejów tematu żydowskiego w XIX wieku ${ }^{5}$, mnie jednak zajmuje ona tutaj jako opowieść regionalna - obraz kultury Wilna przełomu oświeceniowo-romantycznego. Syrokomla bowiem, skądinąd człowiek poglądów demokratycznych, więc bliskich Lelewelowi i Mickiewiczowi, kreśli w Księgarzu ulicznym logikę przełomu, omawiając perturbacje na rynku książki.

Zdaniem Mieczyslawa Inglota:

intencja narratora zmierza do postawienia tezy, iż to właśnie żydowscy handlarze uliczni nauczyli polską szlachtę - której wystarczał kalendarz - czytać poważną literaturę. [...] Księgarz Syrokomli to nie tylko krzewiciel oświaty, to człowiek mądry, znakomicie zorientowany w wartości sprzedawanych książek ${ }^{6}$.

Pierwsza opinia nie podlega dyskusji, istotnie - Syrokomla zmierza do wykazania, że to Żydzi spopularyzowali książki wśród „jasnych panów”. Ale po pierwsze, nie tylko odbiorca szlachecki został w gawędzie sportretowany jako klient księgarza - przedstawiony przez

Czernianin, Halina Czernianin, Wokół «Tygodnika Wileńskiego» 1815-1822. Studia i szkice, Wrocław 2011, s. 24-29.

4 Władysław Syrokomla, Księgarz uliczny. Gawęda, w: tegoż, Wybór poezji, oprac. Franciszek Bielak, wyd. 2, zmien., BN I, nr 54, Wrocław 1970, s. 389-395, w. 11. Pozostałe cytaty z Księgarza ulicznego wg tego wydania, z numerem wersu po cytacie.

5 Pisze o niej np. Mieczysław Inglot, Postać Żyda w literaturze polskiej lat 18221864, Wrocław 1999, s. 139-145.

6 Tamże, s. 141. 
Syrokomlę obieg czytelniczy jest o wiele bardziej złożony i skorelowany również z kręgami uniwersyteckimi, co mnie tu najbardziej interesuje. Po drugie zaś, krzewicielem oświaty jest Żyd „mądry” raczej mądrością życiową niż książkową, zdeterminowany głodem (więc rozumiejący głodnych), który „wartość” książek ustala przede wszystkim na podstawie prawa popytu, $\mathrm{z}$ istotnym jednak zastrzeżeniem. Wyznaje on wprawdzie, że rozpoznaje cenne druki i może poprawiać omyłki w „Bentkowskim”, ale są to umiejętności pozwalające orientować się w materialnej postaci dzieł (data wydania itp.) i szacować ich wartość bibliofilską, nie zaś naukową czy literacką. „Nieuczoność” mądrego Żyda staje się zresztą źródłem gawędowego dystansu - dobrotliwej ironii - narratora w stosunku do bohatera i pozwala dyskretnie wziąć w nawias przesady zależność „rewolucji” oświatowej na Litwie wyłącznie od działań żydowskich księgarzy.

Zacznijmy od ostatniej kwestii: Żyd-bukinista na wstępie zostaje nazwany „Nestorem księgarzy”, w zakończeniu zaś tekstu ochlapany błotem przez karetę właściciela dostatniej, złoto-aksamitnej księgarni - i wówczas górnolotnie mówi: „Och! na co ja stworzyłem tę literaturę?!” (w. 128). Z uśmiechem musimy również czytać komentarze bohatera, którymi puentuje on na przykład szeroki gest "profesorskich figur” - jak Groddeck - gotowych słono płacić za inkunabuły: „A ja tylko sprzedając ściskam ramionami, / Bo na co im te książki, kiedy piszą sami?” (w. 47-48). W tym tonie, oddającym prostoduszny, kupiecki sposób myślenia księgarza, utrzymana jest również wizja oświeceniowo-romantycznego przełomu. Miałby on sprowadzać się do zamiany dużych książek na małe:

No!... pana Mickiewicza zabłysnęła chwała;

Ale już postarzałem... broda posiwiała,

Ręce znużone dziełmi Tacyta, Plutarcha, Wsparłem, ot, na tymi kiju, stary patriarcha;

I nieraz, gdy książeczkę roznosiłem małą, Samemu na ten towar patrzeć się nie chciało, Bo do czego to warto? tom taki niespory! Jam przywykł do in folio lub quarto maiori. 
Żyd zmienia zdanie na temat wartości dzieł Mickiewicza i uznaje, że ten „musi być większy od Horacyjusza” (w. 104), kiedy w pół godziny udaje mu się sprzedać dziesięć „książeczek” autora Grażyny.

Rozumiemy teraz, że kiedy Mickiewicz pisze w wierszu Do Joachima Lelewela o nieobarczaniu przezeń księgarzy, to ma na myśli nie tylko powściągliwość pisarską historyka, ale i zewnętrzną skromność jego dzieł. Istotnie, gdy przyjrzeć się publikacjom Lelewela sprzed momentu pisania wiersza, to prócz dwóch prac poświęconych starożytności, które wypełniają opasłe tomy ze składanymi mapami ${ }^{7}$, dominują wszelkiego rodzaju „pisma pomniejsze" ${ }^{8}$ : recenzje, rozbiory, artykuły prasowe i rozprawy. Również ich postać graficzna - od gatunku papieru i staranności zecerskiej po oszczędnościową wersję wszelkich rycin - daleka jest od ozdobności „wydań bogatych”, o jakich mówi uliczny księgarz Syrokomli w odniesieniu do druków z epoki staropolskiej, na przykład kroniki Stryjkowskiego. Gawędowy bukinista dorzuca, że „Groddeck, Czacki, Śniadecki popisali tomy” (w. 50), które wprawdzie „szły jak asygnata” (w. 51), ale zostały widać przez Syrokomlę wliczone do epoki foliałów, albowiem „małe” nie były.

Wszystkie te procesy, które można by nazwać demokratyzacją kształtu książki, nie rozpoczęły się w Wilnie (ani gdzie indziej) w epoce Lelewela i Mickiewicza. To jeszcze plon oświeceniowego zasiewu, wzmocniony upodobaniami obu autorów do - by tak rzec narracyjnych drobiazgów. Tak więc zmieniony format książki, jej skromniejsza zewnętrzna postać musiały być traktowane w Wilnie jako pieczęć nowości, skoro zwracają na to uwagę znawcy kultury miasta z dwóch różnych generacji: Mickiewicz i Syrokomla. Na zewnętrznym kształcie owa nowość przecież się nie kończy, gdyby bowiem pójść tropem proponowanej przez Rogera Chartiera historii książki, trzeba by uznać, że wydawca jest jej współautorem, materialna

${ }^{7}$ Joachim Lelewel, Badania starożytności we względzie geografji, Wilno 1818 (591 s.), oraz tegoż, Dzieje starożytne. Od początku czasów historycznych do drugiey połowy wieku szóstego, ery chrześcijańskiey, Wilno 1818 (505 s.).

8 Zob. Joachima Lelewela pisma pomniejsze geograficzno-historyczne, Warszawa 1814 . 
zaś postać książki należy do sposobów dookreślania zawartych tam znaczeń i wpływa na styl lektury ${ }^{9}$.

Księgarz uliczny najciekawszy jest jednak jako świadectwo ewolucji gustów w dziedzinie tego, co się czyta. Mieczysław Inglot uważa, że według Syrokomli gusta te zależały ściśle od chronologii powstawania dzieł i po prostu nowsze dzieła wypierały starsze:

Tak jak z koncertu Jankiela można odczytać historię Polski przełomu wieków, tak też w opowieści księgarza prześledzić można dzieje przemian literackich. Pamięć księgarza sięga czasów przedoświeceniowych. I wtedy padają nazwiska Reja, Wujka, Paprockiego, Stryjkowskiego, ale także Benedykta Chmielowskiego z Nowymi Atenami. Ciepło wspomniano oświecenie wileńskie (Groddeck, Czacki, Śniadecki) i oczywiście romantyzm (apoteoza Mickiewicza i Lelewela). A także nadal popularne, co więcej, zastępujące zmarłych wielkich romanse Waltera Scotta ${ }^{10}$.

Wydaje się jednak, że choć Syrokomla przedstawia dwa obiegi czytelnicze - nazwijmy je: uniwersytecki i szlachecki (na tym ostatnim koncentruje się Inglot) - w obrębie których przemiany zachodzą niejednocześnie i w różnym tempie, to $\mathrm{w}$ obu gawędziarz nie wykracza poza pokolenie filomackie. Akcję Księgarza ulicznego można zresztą dość precyzyjnie datować: rozgrywać się ona musi pomiędzy datą śmierci Mickiewicza a datą śmierci Lelewela („pan Joachim wyjechał - pan Mickiewicz w grobie...”, w. 116), czyli pomiędzy 1855 a 1861 rokiem, obejmować zaś „lat sześćdziesiąt blisko”, bo tyle czasu stoi pod wileńskim murem żydowski bukinista ze swoim kramem. Nazwiskami XVI-wiecznych pisarzy, które wymienia bohater, nie sposób mierzyć rozmiarów jego pamięci (jak czytamy u Inglota) - są to po prostu autorzy sprzedawanych książek, ich obecność sygnalizuje tylko koniunkturę na staropolskie druki w okresie przełomu romantycznego lub jej brak, i to właśnie wydaje się bardzo interesujące.

9 Paweł Rodak, Pismo, książk, lektura. Rozmowy: Le Goff, Chartier, Hébrard, Fabre, Lajeune, przedm. Krzysztof Pomian, Warszawa 2009, s. 79.

10 Mieczysław Inglot, Postać Żyda w literaturze polskiej lat 1822-1864, dz.cyt., s. 141. 
Można bowiem powiedzieć, że Księgarz uliczny pokazuje długofalowe skutki zjawisk, których przyczyny zostały opisane w Mickiewiczowskim wierszu Do Joachima Lelewela. Od innej zaś strony patrząc, Syrokomla pozwala zrozumieć, jak to się stało, że Mickiewiczowskie dzieła zawędrowały pod strzechy.

Gawęda ma konstrukcję ramową, narrator w pierwszych dwóch fragmentach zarysowuje historię gustów czytelniczych, od epoki kalendarza i arendarza po czasy Scotta i Kraszewskiego, i wprowadza postać sprawcy tej przemiany; $w$ ostatnim zaś pokazuje przegraną obnośnego księgarza w starciu z nowoczesną księgarnią. Środek utworu wypełniają wspomnienia tytułowego bohatera i z nich możemy się dowiedzieć, jakim mechanizmom zawdzięcza Litwa to, że „dziś cała czyta”. We fragmentach zewnętrznych, ramowych, mówi się o zmianach obejmujących przede wszystkim prowincję litewską, „pańskie pałace” i „szlacheckie chaty” - w monologu księgarza z kolei uwaga skierowana jest tylko na Wilno $\mathrm{z}$ centrum $\mathrm{w}$ postaci uniwersytetu, z „profesorskimi figurami” i tłumem „akademików” (tu: studentów).

Działalność Żyda-księgarza rozpoczyna się w momencie, kiedy w „szlacheckiej chacie” za wszystkie książki wystarcza „wileński kalendarz”, w mieście zaś - gdzie Żyd-księgarz ustawia swój kram czyta się wówczas klasyków starożytnych. W Wilnie trwa zatem epoka, której atmosferę w wierszu Do Joachima Lelewela Mickiewicz oddaje, pisząc o „ruszaniu spod grobów” przez historyka „greckich i Rzymian cieni”. Wcześniej poeta wspomina o fascynacji poezją grecką i rzymską w Pieśni filaretów, potem kolejny raz wraca do tego w IV i III części Dziadów, gdzie Lelewel znowu osobiście patronuje „szaleństwom” wzniecanym przez „starożytne dzieje”. Syrokomla lata owego „czarodziejskiego” ożywiania antyku przedstawia w sposób najbliższy właśnie Pieśni filaretów, w której - pamiętamy - mowa o bawieniu się „jak Greki” i biciu „jak Rzymianin”"1 w Księgarzu ulicznym również dominuje obywatelski wykład starożytnych:

\footnotetext{
11 „W ksiąg greckich, rzymskich steki / Wlazleś, nie żebyś gnił; / Byś bawił się jak Greki, / A jak Rzymianin bił”. Adam Mickiewicz, Pieśn filaretów, w: Dzieła, t. I: Wiersze, oprac. Czesław Zgorzelski, Warszawa 1993, s. 45.
} 
Gdy wielka pieśń i mądrość Hellady i Romy

Górowała nad naszej mądrości atomy,

Kiedy w słowie Platona, w Horacego nucie

Znajdowano Wielkości i Piękna poczucie -

On [księgarz] sprzedawał łacińską książeczkę in quarto,

Zabrudzoną z początku, a z końca odartą.

Sprzedał za kilka groszy i w dodatku powie:

„Niech pan czyta szczęśliwie, niech służy na zdrowie”.

Zdrowież było w tych książkach! słowo wrzące czynem

Naczytawszy się Rzymian, byłeś Rzymianinem,

Duch olbrzymiał w potęgę, opływał w rozkoszy

Za ubogą zapłatę kilkunastu groszy.

[w. 21-32]

Przywołany obrazek pochodzi z partii narratora, a nie bohatera gawędy; ten drugi wróci jednak za chwilę do sprawy fascynacji Romą i Helladą wśród „akademików” wileńskich - oglądanej z własnego, kupieckiego punktu widzenia. Warto już tutaj zauważyć pewien element, który siłą rzeczy nie mógł się pojawić w utworach Mickiewicza z okresu filomackiego. Pisze Syrokomla mianowicie o czasach, „gdy wielka pieśń i mądrość Hellady i Romy / Górowała nad naszej mądrości atomy", obiera więc perspektywę porównawczą, świadomy, że epoka "górowania” Hellady i Romy okaże się epizodem w dziejach Uniwersytetu Wileńskiego, etapem w drodze do narodzin „naszej” pieśni. Podobnie przemawia księgarz, który przygląda się temu epizodowi z perspektywy popytu na starożytne dzieła, a potem na te, które z „naczytania się Rzymian” wyrosły na rodzimym już gruncie:

Rarytne były czasy! a książek ogromy,

Groddeck, Czacki, Śniadeccy popisali tomy.

Dzieła, choć naukowe, szły jak asygnata,

Dużo ich sprzedawałem w staroświeckie lata.

[w. 49-52]

O ile Groddeck był neohellenistą, o tyle Czacki i Śniadeccy raczej ludźmi oświecenia (bardziej niż klasycyzmu), którzy znajomość 
klasyków greckich i rzymskich próbowali wykorzystać do budowania podstaw polskiej geografii, astronomii, piśmiennictwa, prawoznawstwa, historiografii. Czasy były „rarytne”, jak mówi księgarz, ale popyt na tego rodzaju dzieła nie mógł się swobodnie rozwijać przez ograniczenia kieszeni „akademików”, przy czym chodzi tym razem o studentów (wspomniany Groddeck był w stanie płacić „aż cztery talary" za potrzebną książkę):

A był to lud ubogi, obciążony pracą,

Niejeden chciałby kupić... a tu nie ma za co!

Targuje, zwraca książkę, a łza mu się kręci.

To jak tak myślę sobie: No szkoda mi dzieci,

Dam na kredyt lub w zamian literackie śmieci:

Od Baki do Newtona wszystko mi się przyda.

A poczciwi panicze pokochali Żyda

[w. 61-68]

Pomysł księgarza (nie wiadomo, na ile historyczny), by wprowadzić transakcje „w zamian”, okazał się brzemienny w skutkach w wymiarze nie tylko finansowym - ujawnił nam, co zdaniem Syrokomli liczyło się wówczas do „literackich śmieci”. Już w tym fragmencie padają nazwiska księdza Baki i Newtona pospołu, co mogłoby dziwić, jako że są to postaci $z$ antypodów świata książek pokolenia filomackiego, i jedynie to je łączy. Syrokomla jednak wiernie pamiętał sympatie i antypatie „rówieśników Mickiewicza”, którzy na Bace się nie poznali, „Jego Newtońskiej Mości” doradzali zaś uwzględnienie siły braterstwa ${ }^{12}$. Ale kiedy uświadomimy sobie, że student wileński sprzedawał (oddawał?) Newtona i Bakę, by nabyć „Grodka”, Śniadeckiego i Czackiego, to jasne się staje, że chodziło o wybór między książkami, „które mogły człowieka publicznego i prawdziwego

\footnotetext{
12 Newton, jak wiadomo, jest jednym z bohaterów Pieśni filaretów, zob. także Maria Cieśla-Korytowska, O romantycznym poznaniu, Kraków 1997, s. 19-29, oraz Aleksander Nawarecki, Czarny karnawat. «Uwagi śmierci niechybnej» księdza Baki - poetyka tekstu i paradoksy recepcji, Wrocław 1991, s. 176-206.
} 
kształcić obywatela"13 (za co w Panowaniu króla polskiego Stanisława Augusta... chwalił Lelewel zreformowane, a więc i wileńskie szkolnictwo), a każdą inną, mniej pragmatyczną wiedzą. Zatem autor Księgarza ulicznego w swojej literackiej opowieści o Wilnie z czasów filomackich potwierdza rozpoznania świadka epoki - oraz jej historyka - zawarte w wierszu Do Joachima Lelewela. Na tym nie kończą się korzyści z pomysłu księgarza, by transakcjami wymiennymi sycić głód książkowy biednych akademików:

W zamianę dostawałem grube folijały:

Rejów, Wujków, Paprockich, Stryjkowskich zbiór cały,

Łazarzów, Piotrkowczyków wydania bogate,

I pamiętam tytuły, pamiętam ich datę.

[...]

Niepopłatny był towar, mało znany komu, To ja... z piętra na piętro... od domu do domu

Obnoszę, pokazuję, rarytność dowodzę, Wypchną mię przez drzwi jedne, ja drugimi wchodzę;

Bo z biedy cóż mam począć? dla kawałka chleba Jasnym panom oświatę narzucać potrzeba.

I trochę rozbudziłem do książek ochotę

[w. 71-74, 77-83]

Urwany w przytoczeniu wątek zmierza w stronę cy towanego już: „No!... pana Mickiewicza zabłysnęła chwała”. By nie wyciągać zbyt daleko idących wniosków z utworu o charakterze w końcu literackim, nie zaś rozprawy naukowej, nastawionej na ścisłe charakteryzowanie praw recepcji, zwróćmy uwagę tylko na literalnie sformułowane uwagi.

Sławę Mickiewicza, od którego zaczyna się fenomen wyrażony w gawędzie formułą "cała Litwa czyta” i który jednocześnie kończy epokę „kalendarza” na prowincji, poprzedza popularyzacja „Rejów”, „Wujków” i „Stryjkowskich”, a więc piśmiennictwa staropolskiego. „Rozczytania” Litwy dokonują żydowscy księgarze, starając się

13 Joachim Lelewel, Panowanie króla polskiego Stanisława Augusta..., dz.cyt., s. 351. 
sprzedać książki, których pozbywają się akademicy, chcący kupić sobie w zamian „Grodka”, Czackiego czy nawet Homera - a więc klasyków greckich i rzymskich, ich oświeceniowych popularyzatorów oraz pierwszych badaczy starożytności słowiańskich. Piśmiennictwo staropolskie, torujące Mickiewiczowi drogę „pod strzechy”, nazwane zostało przez księgarza Syrokomli „niepopłatnym towarem”, na Litwie „mało znanym komu”. Nie wiadomo, czy ostatnia uwaga dotyczyć ma tylko tzw. zwykłego odbiorcy, któremu księgarz proponuje uzyskany od studentów towar, czy również samych studentów. Tak czy owak byłaby to cenna informacja, pokazująca rozwarstwienie gustów literackich na przedmickiewiczowskiej Litwie: podczas gdy dwory szlacheckie żyły jeszcze w epoce „kalendarza” i czekały na Mickiewicza oraz Scotta, Wilno gorączkowo odrabiało straty: zaczytywało się klasykami antyku, polskimi apologetami nowoczesności i badaczami starożytności polsko-litewskich. Jak przystało na czas „ruchu konwencji”, równie dynamicznie wyglądało to, co wypadło z obiegu - w mieście za „literackie śmieci” uchodzili Baka z Newtonem, a i pisarze złotego wieku byli „mało znani komu”.

Autor Ksieggarza ulicznego zdaje się tu jednak „uśredniać” gusta, trzeba bowiem przypomnieć, że Syrokomla - jak to opisał Aleksander Nawarecki ${ }^{14}$ - sam musiał przeżywać specyficzną fascynację księdzem Baką, daleką od „szubrawskiego” szyderstwa i doprowadził do reedycji jego poezji. Pisarzy staropolskich również znał dobrze jako popularyzator „historii krajowej” w Dziejach literatury w Polsce od pierwiastkowych do naszych czasów. Jednak to, o czym pisze w Księgarzu ulicznym na temat kłopotów z piśmiennictwem polskim na Litwie, z popularyzacją „Wujków” i „Stryjkowskich”, wygląda z perspektywy pism Lelewela i Mickiewicza zupełnie wiarygodnie.

W 1806 roku Lelewel jeszcze jako student i jednocześnie członek Towarzystwa Nauk i Umiejętności (potem Filomatycznego) wystąpił na jego forum $z$ dezyderatem, w którym pod postacią metafory ojczyzny-Feniksa zagrzebanej w popiołach przedstawia sytuację polityczną oraz... bibliograficzną i zadania tego rodzaju stowarzyszeń:

14 Aleksander Nawarecki, Czarny karnawat, dz.cyt., s. 223-227. 
Pierwszy jednak [tj. zanim Feniks ostatecznie powstanie] szczebel do osiągnięcia, sercem Polaka uświęconego przedsięwzięcia, upatruję $\mathrm{w}$ wydźwignieniu na widok powszechności, a dotąd po książnicach prochem obsypanych, a wielością lat zakurzonych, najdawniejszych dziejopisów polskich ${ }^{15}$.

Lelewel ma tu na myśli konkretne teksty, tj. kroniki Galla i Kadłubka (do ich krytycznego wydania w niniejszym wystąpieniu sam się zobowiązywał), ale o tym, że inicjatywa miała ogólniejszy zamysł i odnosiła się do upowszechnienia piśmiennictwa dawnej Polski świadczy jej późniejsza kontynuacja przez uczniów Lelewela. Chodzi oczywiście o Mickiewicza (Mieszko, książę Noworódka, Żywila, Grażyna), ale jeszcze czterdzieści lat później ukazuje się bardzo dosłowne potwierdzenie pomysłu Lelewela w postaci Kroniki polskiej, litewskiej, żmudzkiej i wszystkiej Rusi Macieja Stryjkowskiego ${ }^{16}$. Pisana po polsku kronika wymagała „tylko” popularyzacji i objaśnień, obudowania kontekstem historycznym i biograficznym, porównania z innymi źródłami. Był to tekst niejako gotowy do przywrócenia go pamięci zbiorowej i rzeczywiście Mickiewicz wyrywkowo korzystał już z niego przy Grażynie. W powszechnym jednak odbiorze dawne kroniki mogły uchodzić za - jak pisał Syrokomla - „towar niepopłatny”, skoro przygotowanie edycji Stryjkowskiego trwało wiele lat, prawda że niespokojnych. Zatem koniunkturę (nie tylko handlową) na staropolską tradycję w Wilnie Lelewela i Mickiewicza - mieście o złożonej,

\footnotetext{
15 Joachim Lelewel, Głos miany do Towarzystwa Filomatycznego z oświadczeniem się robót, w: Polska. Dzieje i rzeczy jej rozpatrywane przez Joachima Lelewela, t. 19, Poznań 1866, s. 14.

${ }^{16}$ Kronika polska, litewska, żmudzka i wszystkiej Rusi Macieja Stryjkowskiego, wydanie nowe, będące dokładnem powtórzeniem wydania pierwotnego królewieckiego z roku 1582, poprzedzone wiadomościa o życiu i pismach Stryjkowskiego przez Mikołaja Malinowskiego, rozprawa o latopisach ruskich przez Daniłowicza pomnożone..., t. 1-2, Warszawa 1846. Mikołaj Malinowski był uczniem i współpracownikiem Lelewela z czasów wieleńskich (zbierał m.in. informacje do drugiego tomu Bibljograficznych ksiag dwojga), podobnie jak Ignacy Daniłowicz, profesor Uniwersytetu w Wilnie, znakomity prawoznawca oraz wydawca dawnych statutów i kodeksów (przygotowywał z Lelewelem edycję statutów litewskich).
} 
wielojęzycznej kulturze literackiej w okresie przednowoczesnym ${ }^{17}$ trzeba było dopiero budować, nie powstała ona automatycznie, w jakimś odruchu patriotycznym, wraz z krachem I Rzeczypospolitej. W świetle Księgarza ulicznego na Litwie początków XIX stulecia ciągle łatwiej było o „wileński kalendarz” (na prowincji) i tomik Homera (w stolicy), a nawet książki oświeceniowe (choćby Czackiego), niż na przykład o piśmiennictwo staropolskie. Tymczasem właśnie ono mogło stać się tym ogniwem tradycji, które należy do łańcucha z okresu przed „zerwaniem” - rozbiorowym, a potem modernistycznym.

Poszukiwaniu owego ogniwa Lelewel poświęcił swoich Bibljograficznych ksiag dwoje, do których wiadomości zbierali mu - systematycznie bądź dorywczo - znajomi i przyjaciele, niektórzy też pragnęli zostać jej pozytywnymi bohaterami. Oto fragment listu Michała Balińskiego, dowodzący zarówno pośrednictwa Żydów w wyszukiwaniu źródeł staropolskich, jak i ekscytacji realizującą postulat tego rodzaju zbieractwa inicjatywą wydawniczą Lelewela:

Już dzięki Bogu przy ciągłem moiem staraniu w Bibliofilowskim że tak powiem zapale, przy nieustannych handlach z starozakonnymi bukinistami tutejszemi, zbiór móy xiążek dawnych polskich urósł znacznie, AM więc coś i o miastach choć może nie wszystko. Któż to wie! może, kiedy się będzie drukował 3-ci tom Bibliograficznych Ksiąg, i o exemplarzach moiego skromnego zbiorku, można będzie coś zacytować, tak iak o bibliotekach Ostrowskiego, Aloiz.[ego] Osińskiego, Raczyńskiego i innych, bo się pochwalić, udało mi się wyszperać między innemi kilka ciekawych rzeczy ${ }^{18}$.

W oczach Balińskiego, który należał do elity filomackiego Wilna, a z Lelewelem był związany przede wszystkim przez „Tygodnik

\footnotetext{
17 Złożoność wileńskiego rynku książki w średniowieczu i wczesnej nowożytności potwierdzają badania Jakuba Niedźwiedzia. Zob. tegoż, Kultura literacka Wilna (1323-1655). Retoryczna organizacja miasta, Kraków 2012, s. 58-8o i 119-222.

18 List Michała Balińskiego do Joachima Lelewela, Wilno, 15/27 lutego 1827, w: Kazimierz Jasiulaniec, Z korespondencji Joachima Lelewela z Michałem Balińskim, odbitka Z „Ateneum Wileńskiego”, rocznik XIV, 1939, z. 1, s. 246 (10). Zgodnie $\mathrm{z}$ decyzją wydawcy pisownia nie została zmodyfikowana.
} 
Wileński” (redagował to pismo), Bibljograficznych ksiąg dwoje powinno być wydawnictwem seryjnym i pełnić rolę ciągle aktualizowanego forum „szperaczy” dawnych polskich książek. Podobnymi motywami kierował się widocznie sam autor dzieła, Lelewel, co tłumaczył we wstępie, nawiązując do swojej pracy w bibliotece warszawskiej:

$\mathrm{Z}$ moich czasowych, przez lata 1818-21 zatrudnień, gromadziło się z wolna różnych wiadomości bibliograficznych i historycznych, które kraj nasz, a po wielkiej części literaturę narodową i narodowe dzieje obchodzić mogły. Były one różnego rodzaju, mało styczne z sobą, a chęć udzielenia ich lub powtórzenia wzrastała ${ }^{19}$.

Wrócić jednak trzeba do młodzieńczego programu Lelewela i do jego pisemka filomackiego. W grę wchodziła bowiem jeszcze inna trudność związana $\mathrm{z}$ rodzimymi kronikami, a wynikała ona $\mathrm{z}$ tego, że zwykle historię piszą zwycięzcy:

Najdawniejsi pisarze nasi łożyli prace nie tak dla rodaków, jak dla świata, pióro swoje przystroili nie ojczystym, ale niegdyś Panów ziemi językiem. Chcąc rodakom nieść w dziejach narodowych posługę, rzućmy się do zrucenia [!] obcej togi z naszych pisarzy, a przyodzianych w strój ojczysty światu drukiem starajmy się ogłosić. Może przez to budzimy w rodakach przykłady Wagów, Albertrandych [!], Naruszewiczów. Zjawią się podtenczas barwą przyjemności i piękności ozdobne pióra, które wypadki rodowite przez naocznych świadków spisane powtórzą ${ }^{20}$.

Proponuje tu Lelewel tłumaczenie kronik na polski, zarówno z ,języka Panów”, a więc łaciny, na przykład Galla, jak i ze staroruskiego Nestora. Nie wiadomo, co historyk ma na myśli, pisząc o zjawieniu się piór ozdobnych w „przyjemności i piękności” zainspirowanych - jak

\footnotetext{
19 Joachima Lelewela bibljograficznych ksiag dwoje, w których rozebrane i pomnożone zostały dwa dzieła Jerzego Samuela Bandtke. Historja drukarń krakowskich - tudzież historia Biblioteki Uniw. Jagiell. w Krakowie, a przydany Katalog inkunabułów polskich, t. 1, Wilno 1823, s. 11-12.

20 Tamże, s. 15.
} 
się wydaje - tymi przekładami. Na pewno daje tu o sobie znać wielki apetyt na łatwy i powszechny dostęp do annałów „rodowitej” przeszłości. Bliski on był wówczas wielu uczonym, nie zawsze jednak chęć spojrzenia na przeszłość z pozycji „naocznego świadka” prowadziła rzeczywiście do „powtórzenia” wypadków. Był to impuls, którym żywiły się również: literatura i... mistyfikacje.

Obraz roku 1822 w Wilnie, oświetlony literackimi wizerunkami z epoki - pióra Mickiewicza i Syrokomli - nie przynosi wizji rewolucji, której dokonuje w pojedynkę autor Romantyczności. Przełom polegał raczej na „rarytności [tych] czasów”, ożywieniu umysłowym, kiedy książki w Wilnie „szły jak asygnata”, gusta czytelników zaś mieszały się i zmieniały błyskawicznie: Horacego wypierał Czacki, Śniadeckiego Stryjkowski, tego z kolei „pan Mickiewicz”. Być może wielkość owych czasów wyrastała z prozaicznego dość zjawiska w naszej części Europy: gorączki odrabiania strat i zapóźnień, która nie sprowadza się tylko do kopiowania dominujących kultur, lecz w pewnym momencie przeradza się w rodzimą „gorączkę romantyczną".

\section{Summary \\ 'Splendid' Times ['Rarytne' czasy]. On the Romantic Turning Point in Władysław Syrokomla’s Księgarz uliczny}

The article is interested in looking at the dynamics of the Romantic turning point from the perspective of the changes in the book market in Vilnius in the first half of the nineteenth century. These changes are the subject of literary and historiographical texts by Adam Mickiewicz, Joachim Lelewel, and Władysław Syrokomla. The author focuses primarily on Syrokomla's Ksiegarz uliczny [Street bookseller], analysing it in the context of the works of the Romanticism 'lawgivers' as an indirect testimony to the evolution of literary preferences and external shape of books, their circulation, types of readers, and bookselling trends.

Danuta Zawadzka (Uniwersytet w Białymstoku) - dr hab., adiunkt w Instytucie Filologii Polskiej UwB (Zakład Literatury Oświecenia i Romantyzmu), kieruje Zespołem Badań Regionalnych. Interesuje się związkami literatury 
z historią i historiografią, a także literaturą w kontekście pamięcioznawstwa, narracji tożsamościowych, badań centro-peryferyjnych, nowego regionalizmu i geopoetyki. Autorka książek: Pokolenie klęski 1812 roku. O Antonim Malczewskim i odludkach (Warszawa 200o), Lelewel i Mickiewicz. Paralela (Białystok 2013), współredaktorka (wraz z Grażyną Charytoniuk-Michiej i Katarzyną Sawicką-Mierzyńską) tomu Sokrat Janowicz - pisarz transgraniczny. Studia, wspomnienia, materiały (Białystok 2014). Publikowała również w „Pamiętniku Literackim”, „Sensus Historiae”, „Czasopiśmie Zakładu Narodowego im. Ossolińskich”, „Wieku XIX”, „Przeglądzie Humanistycznym”, „Poznańskich Studiach Polonistycznych”, „Słupskich Pracach Filologicznych”. Współpracuje z „Białostockimi Studiami Literaturoznawczymi”. 